\title{
Maize yield projections under different climate change scenarios in different districts of Punjab
}

\author{
NAVNEET KAUR* and PRABHJYOT KAUR \\ School of Climate Change and Agricultural Meteorology, Punjab Agricultural University, Ludhiana-141004 \\ Email:navneetkpau@gmail.com
}

\begin{abstract}
The study aimed to find out possible changes in climatic data (temperature and rainfall) from the regional climate model viz. PRECIS(Providing Regional Climates for Impact Studies)under different SRES scenarios (A1B, A2 and B2 scenario) by the mid (2021-2050) and end (2071-2100) century at six locations of Punjab representing different agroclimatic zones and to study their impact on maize yield using the crop growth simulation model. The results revealed that the different zones of the state are expected to be warmer during the mid century and this trend has been projected to continue by the end of century because of increase in maximum and minimum temperature at all the locations. The CERES-Maize simulated significant decrease in duration and grain yield of maize crop under projected climate scenarios. The reduction in the crop duration and grain yield was found to be more under the A1B and A2 scenario (high emission scenario) followed by B2 scenario (low emission scenario)due to adverse effects on crop physiology.
\end{abstract}

Keywords: Maize, climate change scenario, crop duration, yield, Punjab

The anthropogenic activities such as deforestation, industrialization, fossil fuels etc. have resulted in imbalance of the atmospheric composition of the greenhouse gases (GHGs). The increased $\mathrm{CO}_{2}$ concentrate can affect plant growth directly through accelerating the photosynthetic activity but indirectly by changing temperature and precipitation patterns of a reginon (Dubrovsky et al. 2000). Rupakumar et al (2006) simulated the local climatic conditions of India by using PRECIS model for the baseline 1961-1990 as well as 2071-2100 under the SRES scenarios A2 and B2.Lunagaria et al. (2011) validated PRECIS projection for baseline period in middle Gujarat. Navneet Kaur and Prabhjyot Kaur (2016) used PRECIS model to project climate at Ludhiana, Punjab, while Patel et al. (2012) projected climate for different districts of Gujarat using PRECIS model. The crop growth simulation model have been widely used to assess the impact of climate change on different crops in India (Patel et al. 2015; Yadav et al. 2015). The present study is aimed to study the projected climate data in different parts of Punjab and their possible impact on maize yield.

\section{MATERIALS AND METHODS}

The daily simulated data for maximum temperature, minimum temperature and rainfall data for the baseline period (1961-1990); data under A1B scenario for mid century
(2021-2050); and under A1B (2071-2098), A2 and B2 (2071-2100) scenarios for the end of $21^{\text {st }}$ century were downscaled using PRECIS model.

The actual historical data (as per availability) and baseline data 1984-1987 for Ballowal Saunkhri; from 19711980 for Amritsar, Jalandhar, Ludhiana and Patiala; and from 1977-1980 for Bathinda (Table 1) was used to derive the correction functions. These correction functions were then used to correct the model output data. The weather data for kharif season (May-October) were analyzed to quantify the changes in maximum temperature $\left({ }^{\circ} \mathrm{C}\right)$, minimum temperature $\left({ }^{\circ} \mathrm{C}\right)$ and rainfall $(\mathrm{mm})$ from the baseline period.

The calibrated and validated CERES-Maize model was then employed for simulating the growth duration and yield of maize for kharif season during the present time period $(1990-2015)$. The simulations were done for the recent 15 -year time period as it can be safely assumed that the contribution of technological advancement is uniform during that period. Further to assess the changes in growth duration and yield of maize, the simulations were done under futuristic A1B scenario (2021-2050), A1 B scenario (20712098), A2 scenario (2071-2100) and B2 scenario (20712100). Further, trend analysis of the simulated growth duration and yield data under all the climate change scenarios was done to assess projected changes per year by the end of century. 
Table1: Latitude and longitude of different locations under study in Punjab

\begin{tabular}{llll}
\hline S No & Location (Period of data used) & Latitude & Longitude \\
\hline 1 & Ballowal Saunkhri(1984-1990) & $31^{\circ} 31^{\prime} 55^{\prime \prime} \mathrm{N}$ & $75^{\circ} 54^{\prime} 56^{\prime \prime} \mathrm{E}$ \\
2 & Amritsar(1971-1990) & $31^{\circ} 37^{\prime} 56^{\prime \prime} \mathrm{N}$ & $74^{\circ} 52^{\prime} 25^{\prime \prime} \mathrm{E}$ \\
3 & Jalandhar(1971-1990) & $31^{\circ} 19^{\prime} 55^{\prime \prime} \mathrm{N}$ & $75^{\circ} 34^{\prime} 25^{\prime \prime} \mathrm{E}$ \\
4 & Ludhiana (1971-1990) & $30^{\circ} 54^{\prime} 33^{\prime \prime} \mathrm{N}$ & $75^{\circ} 48^{\prime} 22^{\prime \prime} \mathrm{E}$ \\
5 & Patiala (1971-1990) & $30^{\circ} 19^{\prime} 38^{\prime \prime} \mathrm{N}$ & $76^{\circ} 24^{\prime} 00^{\prime \prime} \mathrm{E}$ \\
6 & Bathinda (1977-1990) & $30^{\circ} 12^{\prime} 32^{\prime \prime} \mathrm{N}$ & $74^{\circ} 57^{\prime} 09^{\prime \prime} \mathrm{E}$ \\
\hline
\end{tabular}

Table 2: Time taken to the maturity of maize crop under climate change scenarios at different locations of Punjab

\begin{tabular}{|c|c|c|c|c|c|}
\hline \multirow[t]{2}{*}{ Locations } & \multirow[t]{2}{*}{ Present time } & \multicolumn{2}{|c|}{ Mid century } & \multicolumn{2}{|c|}{ End century } \\
\hline & & $\mathrm{A} 1 \mathrm{~B}$ & A1B & $\mathrm{A} 2$ & B2 \\
\hline Ballowal Saunkhri & 93 & $83(-10)$ & $73(-20)$ & $79(-14)$ & $82(-11)$ \\
\hline Amritsar & 89 & $79(-10)$ & $67(-22)$ & $74(-15)$ & $79(-10)$ \\
\hline Jalandhar & 90 & $81(-9)$ & $70(-20)$ & $76(-14)$ & $80(-10)$ \\
\hline Ludhiana & 89 & $81(-8)$ & $70(-19)$ & $75(-14)$ & $80(-9)$ \\
\hline Patiala & 89 & $83(-6)$ & $71(-18)$ & $74(-15)$ & $79(-10)$ \\
\hline Bathinda & 84 & $76(-8)$ & $66(-18)$ & $70(-14)$ & $74(-10)$ \\
\hline
\end{tabular}

Figures in parenthesis indicate deviation in time taken to maturity from the present time

\section{RESULTS AND DISCUSSION}

The results of annual and seasonal analysis of corrected data showed that the kharif season temperature and rainfall would increase in future as indicated by positive deviation from baseline (Fig 1). The projections indicate that maximum temperature, minimum temperature and rainfall would increase at all the locations as compared to their normal by the mid and end of the century under all the scenarios. The projected increase is more under the A1B scenario followed by A2 and B2 scenario. The expected increase in maximum temperature is from 2.9 to $8.7^{\circ} \mathrm{C}$, at different locations while the minimum temperature may rise by 3.0 to $7.6{ }^{\circ} \mathrm{C}$, over different locations. The expected increase in rainfall is highest $(1075 \mathrm{~mm})$ at Ballowal Saunkhri and minimum $(117 \mathrm{~mm})$ at Bathinda.

The results of simulated crop duration of maize crop under different scenarios indicated that maturity period of the maize is expected to decrease during the mid and end of the $21^{\text {st }}$ century under different scenarios of climate change (Table 2). During mid century, the duration of maize will reduce by 6 to 10 days at different locations of the state under high emission scenario (A1B), by end of the century, the reduction in duration is expected to be by 18 to 22 days, 14 to 15 days and 9 to 11 days under the A1B, A2 and B2 scenarios, respectively. The reduction in the duration of the maize crop may be due to the increase in temperatures as compared to the baseline under the different scenarios. The A1B and A2 scenario (high emission scenario) predict more decrease in the duration of the crop as temperatures are relatively higher than baseline under this scenario as compared to other scenarios which may result in shortening to the various phenophases of the maize crop by the end of the $21^{\text {st }}$ century.

\section{Changes in yield of crop}

The results of the trend analysis for the grain yield of the maize crop under different scenarios during the mid and end of $21^{\text {st }}$ century show negative and linear trends for all the districts under study indicating that the grain yield may decline during the mid century and end century period (Table 3). The decline in grain yield of the maize crop by the end of the $21^{\text {st }}$ century will be higher under the A1B scenario ( 55 to $83 \mathrm{~kg} \mathrm{ha}^{-1}$ per year) followed by the $\mathrm{A} 2$ (54 to $80 \mathrm{~kg}$ ha $^{-1}$ per year) and B2 scenario ( 35 to $59 \mathrm{~kg} \mathrm{ha}^{-1}$ per year).Patel et al (2012) and Yadav et al (2015) also reported decrease in grain yield under different climate change scenarios.

It has been clear from the Table 3 for the grain yield by the end of the century under different climate change scenarios for different locations of the Punjab state that among all the climate change scenarios, more decrease in grain yield has been predicted under A1B scenario followed 

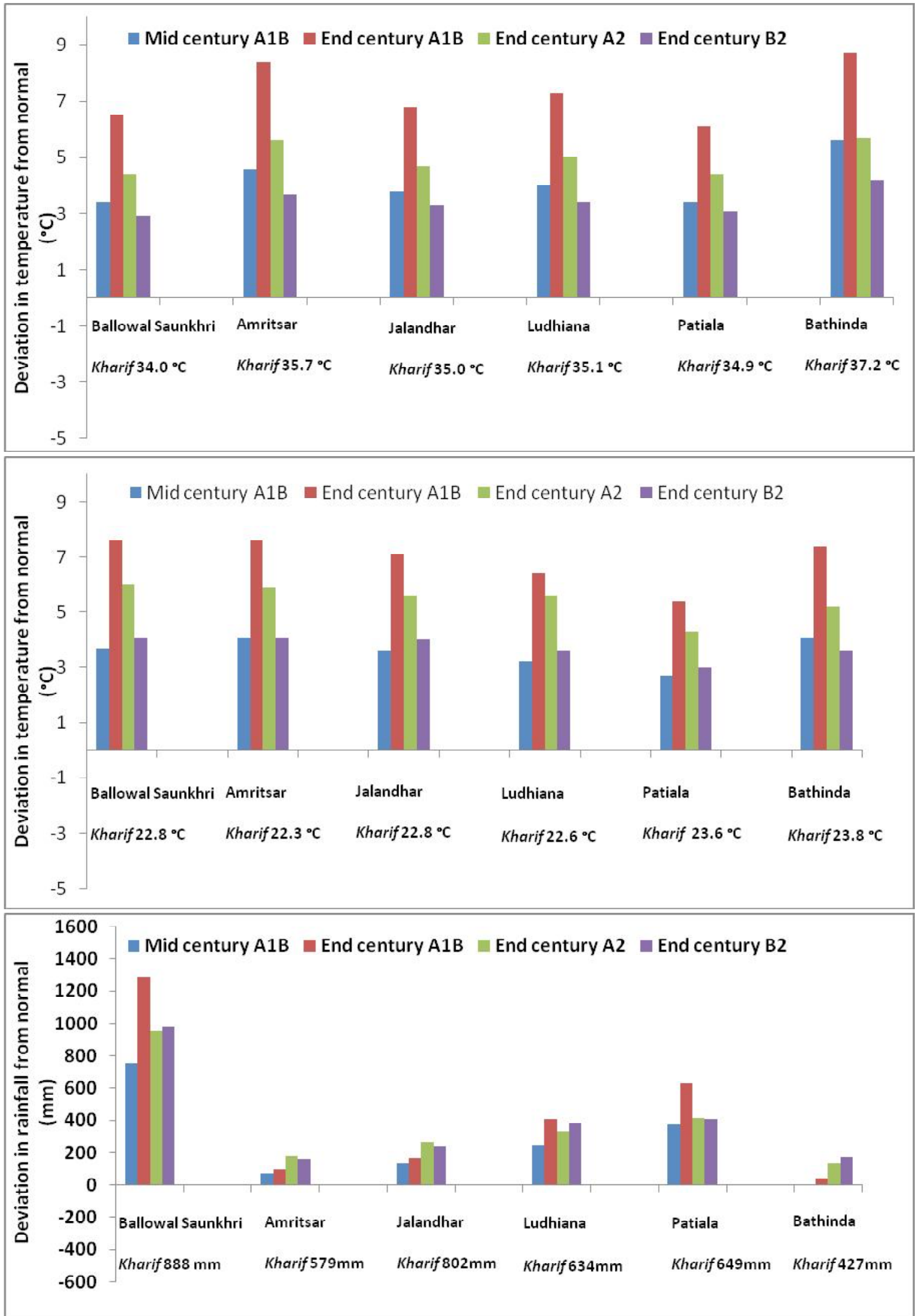

Fig. 1: Deviations in maximum temperature, minimum temperature and rainfall from normal for $k$ harif season the mid and end century under different scenarios at different locations in Punjab state 
Table 3: Trends in grain yield $\left(\mathrm{kgha}^{-1}\right)$ of the maize crop by end century under climate change scenarios for different locations of Punjab

\begin{tabular}{llll}
\hline Location & A1B & A2 & B2 \\
\hline Ballowal Saunkhri & $\mathrm{Y}=-78.35 \mathrm{X}+163738$ & $\mathrm{Y}=-68.97 \mathrm{X}+145826$ & $\mathrm{Y}=-57.18 \mathrm{X}+122176$ \\
& $\left(\mathrm{R}^{2}=0.8417\right)$ & $\left(\mathrm{R}^{2}=0.9365\right)$ & $\left(\mathrm{R}^{2}=0.8626\right)$ \\
Amritsar & $\mathrm{Y}=-82.82 \mathrm{X}+172450$ & $\mathrm{Y}=-78.38 \mathrm{X}+164585$ & $\mathrm{Y}=-58.73 \mathrm{X}+125259$ \\
& $\left(\mathrm{R}^{2}=0.8174\right)$ & $\left(\mathrm{R}^{2}=0.9302\right)$ & $\left(\mathrm{R}^{2}=0.8114\right)$ \\
Jalandhar & $\mathrm{Y}=-83.15 \mathrm{X}+173701$ & $\mathrm{Y}=-69.62 \mathrm{X}+147193$ & $\mathrm{Y}=-51.19 \mathrm{X}+110302$ \\
& $\left(\mathrm{R}^{2}=0.8314\right)$ & $\left(\mathrm{R}^{2}=0.8873\right)$ & $\left(\mathrm{R}^{2}=0.781\right)$ \\
Ludhiana & $\mathrm{Y}=-64.16 \mathrm{X}+134359$ & $\mathrm{Y}=-54.48 \mathrm{X}+115232$ & $\mathrm{Y}=-35.71 \mathrm{X}+77667$ \\
& $\left(\mathrm{R}^{2}=0.7903\right)$ & $\left(\mathrm{R}^{2}=0.798\right)$ & $\left(\mathrm{R}^{2}=0.5666\right)$ \\
Patiala & $\mathrm{Y}=-78.81 \mathrm{X}+165126$ & $\mathrm{Y}=-80.05 \mathrm{X}+167962$ & $\mathrm{Y}=-59.22 \mathrm{X}+126272$ \\
& $\left(\mathrm{R}^{2}=0.9019\right)$ & $\left(\mathrm{R}^{2}=0.9463\right)$ & $\left(\mathrm{R}^{2}=0.8335\right)$ \\
Bathinda & $\mathrm{Y}=-55.61 \mathrm{X}+116129$ & $\mathrm{Y}=-56.34 \mathrm{X}+118384$ & $\mathrm{Y}=-42.55 \mathrm{X}+90760$ \\
& $\left(\mathrm{R}^{2}=0.6434\right)$ & $\left(\mathrm{R}^{2}=0.7128\right)$ & $\left(\mathrm{R}^{2}=0.5275\right)$ \\
\hline
\end{tabular}

by $\mathrm{A} 2$ and $\mathrm{B} 2$ scenario. This is due to the fact that the A1B is the high emission scenario with higher temperatures as compared to the other scenarios. The yield losses under B2 scenario are lesser as compared to the others because it is a low emission scenario and the temperature deviations from the baseline under this scenario are less as compared to the $\mathrm{A} 1 \mathrm{~B}$ and $\mathrm{A} 2$ scenario. The reduction in grain yield of maize hybrids by 15-20 per cent with increasing temperature of 2 ${ }^{\circ} \mathrm{C}$ was also observed by Shrestha et al (2015).

High temperatures can cause morphological, anatomical, physiological and biochemical changes within maize. The crop duration is reduced due to the high temperature stress. Heat stress during kernel development affects cell division, sugar metabolism and starch biosynthesis, reducing subsequent dry matter accumulation within kernels (Commuri and Jones 2001). Similar findings on the reduction in grain yield of maize due to shortening of the growing period have also been reported by Makadho (1996) and Vucetic (2011).

\section{CONCLUSION}

The data on projections of climate data shows that the annual and seasonal temperatures may exceed the temperature and rainfall recorded during the past. The higher temperatures have detrimental effects on the grain development. The results of the study indicate that the maize yield has projected to decline under the different climate change scenarios without any modification in the management practices or the cultivars. This yield reduction may be the result of effect of the elevated temperature and rainfall on the growth and phenology of maize crop. On an average, the maize growing period can reduce by 10 to 22 days by the end of the century. The failure of maize crop may be attributed to the high temperature environments predicted during these crop years which results in poor growth and development of maize crop due to the high temperature.

\section{REFERENCES}

Commuri, P. D. and Jones, R. J. (2001). High temperatures during endosperm cell division in maize: Agenotypic comparison under In vitro and field conditions. Crop Sci., 41: 1122-30 .

Dubrovsky, M., Zalud, Z., Stastna, M. and Trnka, M. (2000). Effect of climate change and climate variability on crop yields. In: Proceedings of the $3^{\text {rd }}$ European Conference on Applied Climatology. October 16-20, Pisa, Italy.

Lunagaria, M.M., Patel, H. R., Shah,A. V., Yadav, S.B., Karande, B.I. and Pandey, V. (2011). Validation of PRECIS baseline (1961-1990) simulation for middle Gujarat agroclimatic zone. J. Agrometeorol., 13 (2): 92-96.

Makadho, J. M. (1996). Potential effects of climate change on corn production in Zimbabwe. Climate Res., 6: 147-51.

Navneet Kaur and Prabhjyot Kaur (2016) Projected climate change under different scenarios in central region of Punjab, India. J. Agrometeorol., 18 (1): 88-92.

Patel, H. R., Lunagaria, M.M., Karande, B.I., Yadav, S.B., Shah, A. V.,Sood, V.K. and Pandey, V.(2015). Climate change and its impact on major crops in Gujarat. $J$. Agrometeorol., 17 (2): 190-193. 
Patel, H. R., Lunagaria, M.M., Karande, B.I., Pandey, V., Yadav, S.B., Shah, A. V., Rao, V.U.M. and Kumar, N.S. (2012). Impact of projected climate change on wheat and maize in middle Gujarat agro-climatic zone. J. Agrometeorol., 14: 134-37.

Rupakumar, Sahai, A. K., Kumar, K. K., Patwardhan, S. K., Mishra, P. K., Revadekar, J. V., Kamala, K. and Pant, G. B. (2006). High resolution climate change scenarios for India for the $21^{\text {st }}$ cemtury. Curr. Sci.,90: 334-45.

Shrestha, U., Amgain, L. P., Karki, T.B. and Dahal, K. R. (2015). Simulation of growth and yield of rainfed maize under varied agronomic management and changing climatic scenario in Nawalparasi, Nepal. J. Maize Res. Dev., 1: $123-33$.

Vucetic, V. (2011). Modelling of maize production in Croatia: present and future climate. J. Agric. Sci., 149: 145-57.

Yadav, M. K., Singh, R. S., Singh, K. K., Mal, R. K., Patel, C. B., Yadav, S.K. and Singh, M. K. (2015) Assessment of climate change impact on productivity of different cereal crops in Varanasi, India. J. Agrometeorol., 17(2): 17984. 